\title{
Mass Transfer Limitation in Different Anode Electrode Surface Areas on the Performance of Dual Chamber Microbial Fuel Cell
}

\author{
${ }^{1}$ Majid Sadeqzadeh, ${ }^{2,3}$ Mostafa Ghasemi, ${ }^{4}$ Ali Ghannadzadeh, \\ ${ }^{5}$ Babak Salamatinia, ${ }^{2,3}$ Tahereh Jafary, ${ }^{2,3}$ Wan Ramli Wan Daud and ${ }^{6}$ Sedky Hassan Aly Hassan \\ ${ }^{1}$ Unité de Catalyse et de Chimie du Solide, \\ UMR 8181 CNRS, Université Lille 1-ENSCL-EC-Lille, Villeneuve d'Ascq, France \\ ${ }^{2}$ Fuel Cell Institute, University Kebangsaan Malaysia, 43600 UKM Bangi, Selangor, Malaysia \\ ${ }^{3}$ Department of Chemical and Process Engineering, Faculty of Engineering and Built \\ Environment, University Kebangsaan Malaysia, 43600 UKM Bangi, Selangor, Malaysia \\ ${ }^{4}$ Department of Process and System Engineering, University of Toulouse, Toulouse, France \\ ${ }^{5}$ Discipline of Chemical Engineering, \\ School of Engineering, Monash University Sunway Campus, Selangor, Malaysia \\ ${ }^{6}$ Department of Biological Environment, \\ Kangwon National University, 200-701, Chuncheon, South Korea
}

Received 2012-09-29, Revised 2012-10-18; Accepted 2012-11-01

\begin{abstract}
In this study, the effect of different electrode surface areas on the performance of dual chamber Microbial Fuel Cells (MFC) was investigated. Four different electrodes with 12, 16, 20 and $24 \mathrm{~cm}^{2}$ surface areas were tested in an MFC system. The $20 \mathrm{~cm}^{2}$ electrode generated an output power of $76.5 \mathrm{~mW} / \mathrm{m}^{2}$ was found to be the highest among all the electrodes tested. This might be due to better interactions with microorganism and less mass transfer limitation. In addition, this indicates that the chances for attachment of bacteria and generation of electricity in larger electrode surface areas might be limited by mass transport and by higher surface area. The output power generation was then followed by the 16,12 and $24 \mathrm{~cm}^{2}$ electrodes which generated $69.6,64.7$ and $61.25 \mathrm{~mW} / \mathrm{m}^{2}$ electricity, respectively.
\end{abstract}

Keywords: Electrode Surface Area, Microbial Fuel Cells, Power Generation, Anode, Mass Transfer

\section{INTRODUCTION}

Nowadays, there are lots of concerns raised due to the exponential increase in the worldwide energy demand whereas the conventional energy sources (mostly fossil fuels) are depleted. Besides that, as reported by Wen et al. (2009), the combustion of fossil fuels has several negative effects on the environment such as $\mathrm{CO}_{2}$ emissions, elevation of earth temperature, climate change. Therefore, introducing renewable sources of green energy is becoming more and more interesting among researchers. Amini et al. (2010) and Heidari et al. (2009) proposed that wastewater organic materials offer a promising alternative energy source. Microbial Fuel Cells (MFC) are a type of fuel cell that converts chemical energy to electrical energy through the action of microorganism as biocatalysts as described by Lovley (2006). Several other factors affect the performance of MFCs such as electrode spacing, electrode materials, catalysts, microbial inoculums, proton exchange membranes, surface area. The biocatalysts used in MFCs are more advantageous than the other parameters of microbial fuel cells due to their biocompatibility and high efficiency.

The attractiveness of MFCs comes from simultaneous wastewater treatment and the production of energy. For electricity production, Ghasemi et al. (2011) have suggested that a soluble electron donor such as neutral red methyl blue, thionine should be oxidized by Corresponding Author: Mostafa Ghasemi, Fuel Cell Institute, University Kebangsaan Malaysia, 43600 UKM Bangi, Selangor, Malaysia 
microorganisms in the anode compartment to produce electrons and protons. The electrons produced by the bacteria can be transferred to the anode by electron mediators as shown by Kim et al. (2002). In essence, Logan et al. (2005) proposed that the generation of current is the nature of microorganism, as they transfer electrons to an electron acceptor through a reduced electron donor.

In order to improve the MFC performance, most researchers concentrate on cathode and microbial community. However, the anode is also a very important limiting factor for power generation as suggested by Biffinger et al. (2007). This is mainly due to the attachment of bacteria on the electrode, which is further enhanced by the type of electrode material used, its structure and surface area; which ultimately increases MFC performance (Qiao et al., 2007). Recently, Liu et al. (2004) found that MFCs operated by a mixed culture, can produce higher power density than those operated by a single culture. This is due to the existence of electrophiles and other groups that can be found within the natural mediators (Behera and Ghangrekar, 2009). Sedighi et al. (2012) and Zhang et al. (2011) showed that these types of microorganisms can also facilitate the transfer of electrons and protons by producing conductive nanorods.

In this research, carbon paper is utilized as the anode electrode, with different surface areas that were inoculated with mixed culture Palm Oil Mill Effluents (POME), to evaluate the effect of surface area on MFC performance.

\section{MATERIALS AND METHODS}

Four Plexiglas dual chamber MFCs, with 120, 160, 200 and $240 \mathrm{~mL}$ were used. Each of the two chambers was separated by a Nafion-117 Proton Exchange Membrane (PEM). The anode electrode was plain Carbon Paper (CP) with areas of 12, 16, 20 and $24 \mathrm{~cm}^{2}$, assembled on four chambers of 120, 160, 200 and 240 $\mathrm{mL}$, respectively. For all MFCs, CP was coated with Platinum $(\mathrm{Pt})$ with a concentration of $0.35 \mathrm{mg} \mathrm{cm}^{-2}$ to be used as the cathode electrode. The anode chamber contained $3 \mathrm{~g}$ of glucose per liter, used as a the carbon source, $0.05 \mathrm{~g}$ yeast extract, used as a nitrogen source, $0.1 \mathrm{~g} \mathrm{KCl}, 0.7 \mathrm{~g} \mathrm{NaH}_{2} \mathrm{PO}_{4} .4 \mathrm{H}_{2} \mathrm{O}, 1.5 \mathrm{~g} \mathrm{NH}_{4} \mathrm{Cl}, 2.5 \mathrm{~g}$ $\mathrm{NaHCO}_{3}$, (all from merck). $10 \mathrm{~mL}$ solution of mineral of wolf and $10 \mathrm{~mL}$ wolf's vitamin solution per liter are used as well. This composition is similar to the one used by Trinh et al. (2009). All electrochemical tests were conducted in a $30^{\circ} \mathrm{C}$ incubator in batch mode. The cathode chamber was filled with a phosphate buffer solution (which consisted of $2.76 \mathrm{~g} \mathrm{~L}^{-1} \mathrm{NaH}_{2} \mathrm{PO}_{4}, 4.26$
$\mathrm{Na}_{2} \mathrm{HPO}_{4} \mathrm{~g} \mathrm{~L}^{-1}, 0.31 \mathrm{~g} \mathrm{~L}^{-1} \mathrm{NH}_{4} \mathrm{Cl}$ and $\left.0.13 \mathrm{~g} \mathrm{~L}^{-1} \mathrm{KCl}\right)$. A type of POME was used for the inoculation of the anaerobic reactor in the anode. The system was connected to a multimeter (Fluke-8846A) to measure the voltage every $15 \mathrm{~min}$ (Ghasemi et al., 2012).

The current was measured using Equation 1:

$\mathrm{I}=\mathrm{V} / \mathrm{R}$

And the power was calculated using Equation 2 as follows:

$\mathrm{P}=\mathrm{I} \times \mathrm{R}^{2}$

where, $\mathrm{I}$ is the current (in Amperes), $\mathrm{V}$ is the voltage (in Volts), $\mathrm{R}$ is the resistance (in Ohms) and $\mathrm{P}$ is the power (in Watts). In the dual chamber MFCs, the electrons generally move from anode to cathode via an external circuit and $\mathrm{H}^{+}$passes from the PEM to reach to cathode as explained by Mohan et al. (2008).

The Coulombic Efficiency (CE) was calculated as the current over the time until the maximum theoretical current was achieved. The evaluated CE over time was calculated using Equation 3:

$\mathrm{CE}=\left(\mathrm{M} \int_{0}^{\mathrm{t}} \mathrm{Idt}\right) / \mathrm{FbV}_{\mathrm{an}} \Delta \mathrm{COD}$

where, $\mathrm{M}$ is the molecular weight of oxygen (32 $\mathrm{g}$ $\mathrm{mol}^{-1}$ ), $\mathrm{F}$ is Faraday's constant, $\mathrm{b}=4$ indicates the number of electrons exchanged per mole of oxygen, $V_{\text {an }}$ is the volume of the liquid in the anode compartment and COD is the change in the Chemical Oxygen Demand (COD) over time, ' $t$ '.

Micrographs were taken of the bacteria using Scanning Electronic Microscopy (SEM, model supra 55vp-Zeiss, Germany). The details of the apparatus are given by Rahimnejad et al. (2011).

\section{RESULTS}

\subsection{Bacteria Characterization and Metabolism}

Figure 1 demonstrates the SEM images of the microbial communities which have been attached to the anode after two months of operation. It could be observed from the micrographs that the carbon papers were covered totally by a mixed culture of bacteria and yeasts. After characterizing of the microorganism it was undrestood that, most of the microbial structures on the anode surfaces were mainly rod-shaped. 

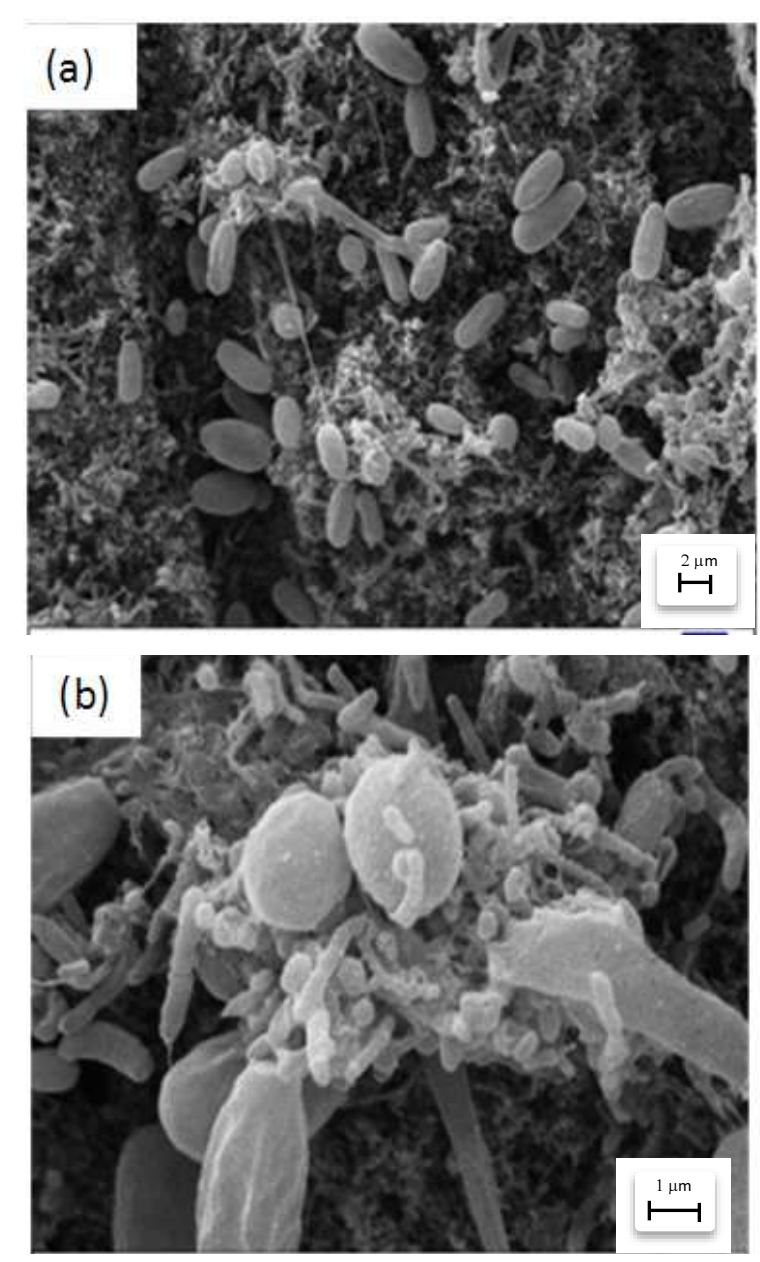

Fig. 1. Different microbial communities on the anode surface, (a) yeast (b) bacteria short rod and yeast

At 1.8-2.2 $\mu \mathrm{m}$ long and 0.25-0.4 $\mu \mathrm{m}$ wide, bacteria cells combined with cocci bacteria and some of the yeast, in sizes ranging from 3-4.5 $\mu \mathrm{m}$.

Zhang et al. (2006) reported in a previous study that diversity in the microbial communities, associated with the anodes in the MFC, was observed with different shapes. The role of attached bacteria is that, they act as a biocatalyst for the conversion of organic substrates to electrons and protons.

\section{DISCUSSION}

\subsection{Anode Performance by Different Surface Areas}

Figure 2 shows the power density curve of different MFCs with different anode surface areas. The data was obtained after 2 months of working under $1000 \Omega$ loads. The maximum power generated by the $12 \mathrm{~cm}^{2}$ electrode was 64.681 at $328.3 \mathrm{~mA} / \mathrm{m}^{2}$. The power density was observed to be elevated when the electrode surface area was increased from $12 \mathrm{~cm}^{2}$ to $16 \mathrm{~cm}^{2}$ and reached 69.5 at $152.26 \mathrm{~mA} / \mathrm{m}^{2}$. This implies that more electrons were transferred from the anode to the cathode, when electrode surface area was increased. The power generated increased further at a $\mathrm{CP}$ anode surface area of $20 \mathrm{~cm}^{2}$ and reached 76.5 at $178.5 \mathrm{~mA} / \mathrm{m}^{2}$. When the surface area was $24 \mathrm{~cm}^{2}$, the power started to decrease to 61.25 at $221.36 \mathrm{~mA} / \mathrm{m}^{2}$. This decline in power density could be attributed to the mass transport limitations of organic substrates to reach the electrode surface for microorganism feeding as suggested by Lorenzo et al. (2010).

Figure 3 shows the polarization curve of the different MFC systems. It is used to measure the internal resistance of the system. The internal resistance of the MFCs was calculated by using the slope of the I-V curve (polarization curve). A lower internal resistance is clearly favoured by the system. The MFC working with an electrode surface area of $20 \mathrm{~cm}^{2}$, showed the lowest internal resistance of $385 \Omega$ among all the MFC systems. This was followed by the MFCs operating with 24,12 and $16 \mathrm{~cm}^{2}$ electrode surface areas, with 496, 513 and $642 \Omega$ internal resistances, respectively. The internal resistance results calculated from the polarization curve showed that there was no special relation between electrode surface area and internal resistance of the MFC system. Therefore, internal resistance depends on other factors such as type of electrode, PEM, media composition. However, by increasing the electrode surface area, the number of microorganisms that can attach themselves to the electrode also increases. However, it should be mentioned that in agreement with the work of Logan (2009) several types of microorganisms are not suitable for electricity generation, as they consume media without producing electricity.

\subsection{Coulombic Efficiency and COD Removal}

Coulombic efficiency and COD removal of the different systems is shown in Fig. 4. It reveals that all MFC systems had high COD removal almost more than $80 \%$. This confirms the role of MFCs in wastewater treatment by efficiently removing COD with a low capital cost. It is also observed in Fig. 4 that the highest CE (14.7\%) belonged to the electrode with $20 \mathrm{~cm}^{2}$ surface area. 
Majid Sadeqzadeh et al. / American Journal of Biochemistry and Biotechnology 8 (4) (2012) 320-325

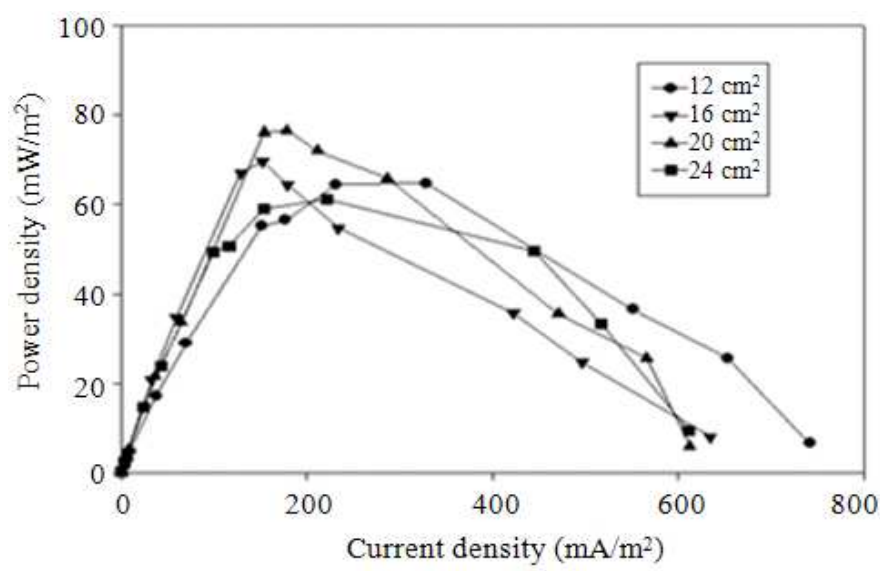

Fig. 2. Power density graph of the different MFCs

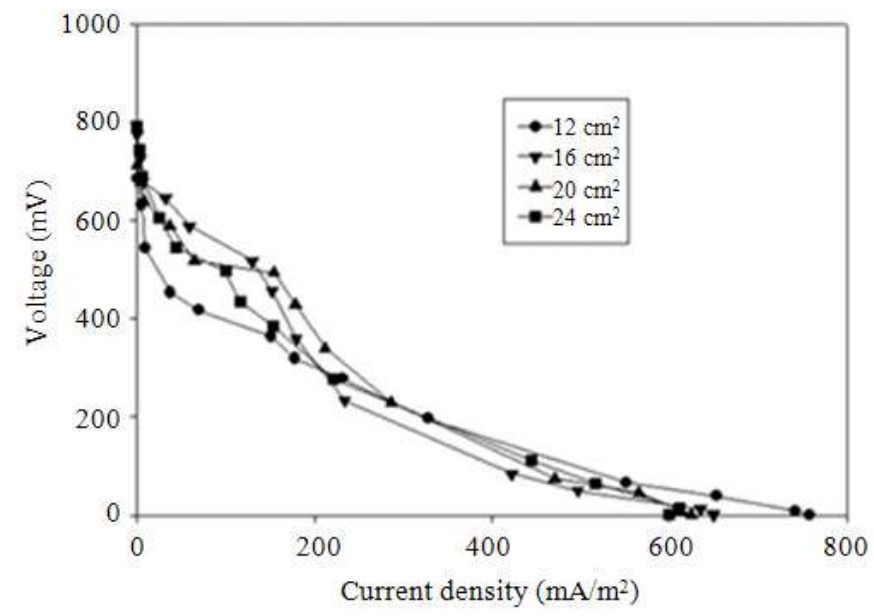

Fig. 3. Polarization curve of the different MFCs

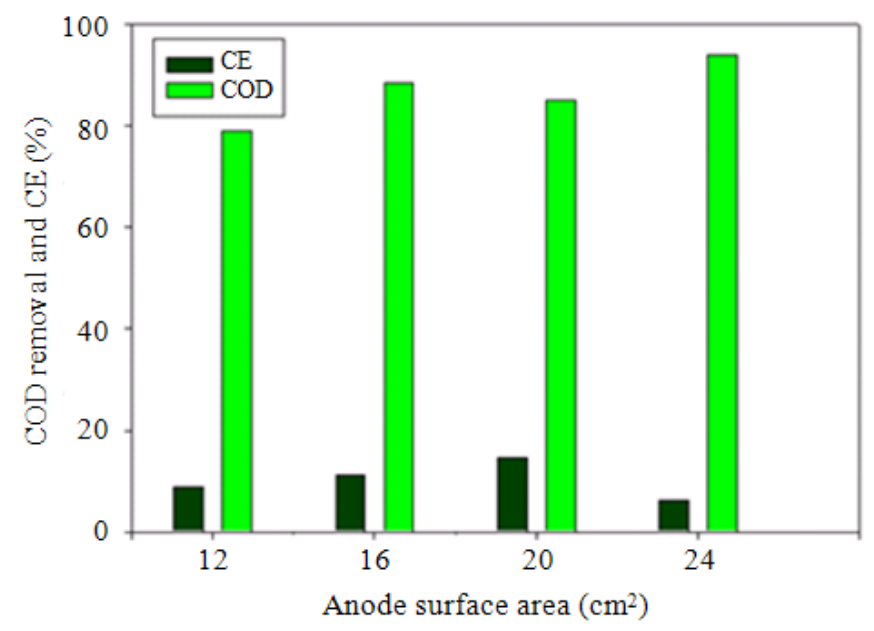

Fig. 4. COD removal and coulombic efficiency of the different MFCs 
The next highest CE (11.3\%) belongs to the electrode with a $16 \mathrm{~cm}^{2}$ surface area, compared to the electrodes with 12 and $24 \mathrm{~cm}^{2}$, which had 8.8 and $6.3 \% \mathrm{CE}$, respectively. This shows that the system with the highest CE percentage generated more power density.

\section{CONCLUSION}

Carbon paper with different surface areas was tested in an MFC. The SEM micrographs showed that several types of bacteria predominantly attached to the CP for the generation of electricity. Also, it can be concluded that after the optimal surface area (which in our study was $20 \mathrm{~cm}^{2}$ ), the power density generated by MFCs declined. This indicates that the chances for attachment of bacteria and generation of electricity in larger electrode surface areas might be limited by mass transport. These findings are the basis of the next objective of this research, which is to find the optimum anode electrode area for better MFC power generation.

\section{ACKNOWLEDGEMENT}

The researcher are grateful for the financial support of the Fuel cell Institute, National University of Malaysia's (UKM) and also for the microbial fuel cell group facilities, which allowed us to complete this research.

\section{REFERENCES}

Amini, M., H. Younesi and N. Bahramifar, 2010. Characterization and optimization of uranium adsorption using chlorella vulgaris: A tool in management of dangerous effluents. J. Biotechnol., 150: 553-554. DOI: 10.1016/j.jbiotec.2010.10.007

Behera, M. and M.M. Ghangrekar, 2009. Performance of microbial fuel cell in response to change in sludge loading rate at different anodic feed $\mathrm{pH}$. Bioresource Technol., 100: 5114-5121. DOI: 10.1016/j.biortech.2009.05.020, PMID: 19539466

Biffinger, J.C., J. Pietron, R. Ray, B. Little and B.R. Ringeisen, 2007. A biofilm enhanced miniature microbial fuel cell using Shewanella oneidensis DSP10 and oxygen reduction cathodes. Biosens. Bioelectron., 22: 1672-1679. DOI: 10.1016/j.bios.2006.07.027

Ghasemi, M., S. Shahgaldi, M. Ismail, Z. Yaakob and W.R.W. Daud, 2012. New generation of carbon nanocomposite proton exchange membranes in microbial fuel cell systems. Chem. Eng J., 184: 8289. DOI: $10.1016 /$ j.cej.2012.01.001
Ghasemi, M., S. Shahgaldi, M. Ismail, B.H. Kim and Z. Yaakob et al., 2011. Activated carbon nanofibers as an alternative cathode catalyst to platinum in a twochamber microbial fuel cell. Int. J. Hydrogen Energy, 36: 13746-13752. DOI: 10.1016/j.ijhydene.2011.07.118

Heidari, A., H. Younesi and Z. Mehraban, 2009. Removal of $\mathrm{Ni}(\mathrm{II}), \mathrm{Cd}(\mathrm{II})$ and $\mathrm{Pb}$ (II) from a ternary aqueous solution by amino functionalized mesoporous and nano mesoporous silica. Chem. Eng. J., 153: 70-79. DOI: 10.1016/j.cej.2009.06.016

Kim, H.J., H.S. Park, M.S. Hyun, I.S. Chang and M. Kim et al., 2002. A mediator-less microbial fuel cell using a metal reducing bacterium, Shewanella putrefaciens. Enzyme Microbial. Technol., 30: 145152. DOI: $10.1016 / \mathrm{S} 0141-0229(01) 00478-1$

Liu, H., R. Ramnarayanan and B.E. Logan, 2004. Production of electricity during wastewater treatment using a single chamber microbial fuel cell. Environ. Sci. Technol., 38: 2281-2285. DOI: 10.1021/es034923g

Logan, B.E., 2009. Exoelectrogenic bacteria that power microbial fuel cells. Nature Rev. Microbiol., 7: 375381. DOI: $10.1038 /$ nrmicro2 113

Logan, J.B.E., C. Murano, K. Scott, N.D. Gray and I.M. Head, 2005. Electricity generation from cysteine in a microbial fuel cell. Water Res., 39: 942-952. DOI: 10.1016/j.watres.2004.11.019

Lorenzo, D.M., K. Scott, T.P. Curtis and I.M. Head, 2010. Effect of increasing anode surface area on the performance of a single chamber microbial fuel cell. Chem. Eng. J., 156: 40-48. DOI: 10.1016/j.cej.2009.09.031

Lovley, D.R., 2006. Microbial fuel cells: Novel microbial physiologies and engineering approaches. Curr. Opin. Biotechnol., 17: 327-332. DOI: 10.1016/j.copbio.2006.04.006

Mohan, S.V., R. Saravanan, S.V. Raghavulu, G. Mohanakrishna and P.N. Sarma, 2008. Bioelectricity production from wastewater treatment in dual chambered Microbial Fuel Cell (MFC) using selectively enriched mixed microflora: Effect of catholyte. Bioresour. Technol., 99: 596-603. DOI: 10.1016/j.biortech.2006.12.026

Qiao, Y., C.M. Li, S.J. Bao and Q.L. Bao, 2007. Carbon nanotube/polyaniline composite as anode material for microbial fuel cells. J. Power Sour., 170: 79-84. DOI: 10.1016/j.jpowsour.2007.03.048 
Rahimnejad, M., M. Ghasemi, G.D. Najafpour, M. Ismail and A.W. Mohammad et al., 2011. Synthesis, characterization and application studies of self-made $\mathrm{Fe}_{3} \mathrm{O}_{4} / \mathrm{PES}$ nanocomposite membranes in microbial fuel cell. Elect. Acta., 85: 700-706. DOI: 10.1016/j.electacta.2011.08.036

Sedighi, M., M. Ghasemi, S.H.A. Hassan, W.R.W. Daud and M. Ismail et al., 2012. Process optimization of batch biosorption of lead using Lactobacillius bulgaricus in an aqueous phase system using response surface methodology. World J. Microbiol. Biotechnol., 28: 2047-2055. DOI: 10.1007/s11274012-1007-4

Trinh, N.T., J.H. Park and B.W. Kim, 2009. Increased generation of electricity in a microbial fuel cell using Geobacter sulfurreducens. Korean J. Chem. Eng., 26: 748-753. DOI: $10.1007 / \mathrm{s} 11814-009-0125-7$
Wen, Q., Y. Wu, D. Cao, L. Zhao and Q. Sun, 2009. Electricity generation and modeling of microbial fuel cell from continuous beer brewery wastewater. Bioresour. Technol., 100: 4171-4175. DOI: 10.1016/j.biortech.2009.02.058

Zhang, E., W. Xu, G. Diao and C. Shuang, 2006. Electricity generation from acetate and glucose by sedimentary bacterium attached to electrode in microbial-anode fuel cells. J. Power Sour., 161: 820825. DOI: 10.1016/j.jpowsour.2006.05.004

Zhang, Y., Y. Hu, S. Li, J. Sun and B. Hou. 2011. Manganese dioxide-coated carbon nanotubes as an improved cathodic catalyst for oxygen reduction in a microbial fuel cell. J. Power Sour., 196: 9284-9289. DOI: 10.1016/j.jpowsour.2011.07.069 